\title{
Study of Sinoatrial Nodal Artery Dominance in Brazilian Human Hearts
}

\author{
Estudio de Dominancia de la Arteria Sinoatrial Nodal en Corazones Humanos Brasileños \\ *,******Frank Silva Bezerra; *Akinori Cardoso Nagato; "Carolina Lourdes Julião Vieira; \\ "Liana Antonicci Reis; "Luciene Novais \& "Samuel Santos Valença.
}

BEZERRA, S. F.; NAGATO, C. A.; VIEIRA, J. C. L.; REIS, A. L. NOVAIS, L. \& VALENÇA, S. S. Study of sinoatrial nodal artery dominance in Brazilian human hearts. Int. J. Morphol., 26(1):47-50, 2008.

SUMMARY: Thirty hearts from adult individuals, 15 from male individuals and 15 female individuals, from the Anatomy Institute of Severino Sombra University were used. After a paramedian incision in the sternocostal joint, a careful dissection was performed in order to expose and identify the sinoatrial nodal artery (SAN), a right or left coronary artery branch. The domain was registered as right, if the right coronary branch irrigated the SAN. The same was listed for the left coronary artery. In addition, cases were both arteries irrigated SAN also were listed. All data, including hearts mass according to gender definition, were compared with previous reports through the variance analysis test (One-way ANOVA) and the post-hoc test of Newman-Keuls with $p \leq 0.05$. Groups were defined as MHL: Hearts from male individuals, data from literature; FHL: Hearts from female individuals, data from literature; MHS: Hearts from male individuals, data obtained from the present study; FHS: Hearts from female individuals, data obtained from the present study. Data from MHL was 22\% heavier than FHL group. MHS group was $41 \%$ heavier than FHS group. Only FHS was $11 \%$ lighter than FHL $(\mathrm{p}<0.05)$. Right coronary domain was present in $80 \%$ and $100 \%$ of the studied cases, male and female, respectively. Only $20 \%$ of the hearts from MHS group showed left coronary domain. No cases of irrigation form both arteries were observed in the present study. The present results indicated higher right sinoatrial nodal artery dominance in all cases studied regardless gender and differences on heart weight were similar to those found in literature descriptions.

KEY WORDS: Heart; Sinoatrial nodal artery; Arterial dominance.

\section{INTRODUCTION}

The advances in the diagnosis of coronary heart diseases have brought to discussion the long forgotten studies in the morphology and anatomy of coronary arteries (Fox et al., 1973; Flaci Jr., 1994). Coronary arteries, as the first branches of aorta artery, supply blood to the myocardium. Coronary found arteries, normally found in pairs, may vary in origin, distribution, number and size. These arteries emit several branches responsible for irrigating the whole surface and interior heart tissue (Mandarim-de-Lacerda, 1990).

Among those branches, the sinoatrial nodal (SAN) artery, which is responsible for irrigating the structure, which is in charge of initiating each heart beat, is one of the most important branches (Sañudo et al., 1998). Anatomical variations of coronary dominance are common, and they are characterized by the presence of a coronary branch irrigating SAN, which could be originated from either right or left coronary artery (Gray \& Mayo, 1988). Therefore, the aim of this study was to investigate the anatomical variance of SNA artery in human hearts compared with previous anatomical reports and/or records.

\section{MATERIAL AND METHOD}

Thirty hearts from adult individuals, 15 men and 15 women, from Anatomy Institute of Severino Sombra University were used for this experiment. The hearts were weighted on a precision balance and data were recorded.

\footnotetext{
* Instituto de Anatomia Humana da Universidade Severino Sombra, Vassouras, Brasil.

* Laboratório de Reparo Tecidual - Departamento de Histologia e Embriologia - Universidade do Estado do Rio de Janeiro, Rio de Janeiro, Brasil.

**** Departamento de Anatomia - Universidade Federal do Rio de Janeiro, Rio de Janeiro, Brasil.
} 
Weights from the hearts analyzed in the present study were compared to those found in literature and among groups though One-way ANOVA and the post-hoc test of NewmanKeuls with $\mathrm{p}<0.05$.

Groups were defined as:

*MHL- Heart weights from male individuals, data from literature ( Gray \& Mayo);

*FHL- Heart weights from female individuals, data from literature ( Gray \& Mayo);

*MHS- Heart weights from male individuals, data obtained from the present study.

*FHS- Heart weights from female individuals, data obtained from the present study.

The identification of the sinoatrial nodal artery (SAN), as either right or left coronary artery branch, was made by a careful dissection thought a paramedian incision in the sternocostal joint. The right coronary artery dominance (RAP) was registered, if the right coronary branch irrigated the SAN (James, 1961). The same was listed for the left coronary artery (LAP). Co-dominance was registered if both coronary arteries branch irrigated the SAN. The incidences of RAP, LAP or co-dominance were registered according to gender.

\section{RESULTS}

Heart weights. Data are presented in Fig. 1. Data from literature showed that male hearts are $22 \%$ heavier than females. MHS group was $41 \%$ heavier than FHS group. No differences were noticed between MHL and MHS. However, FHS group had $11 \%$ lighter hearts than FHL group $(\mathrm{p}<0.05)$.

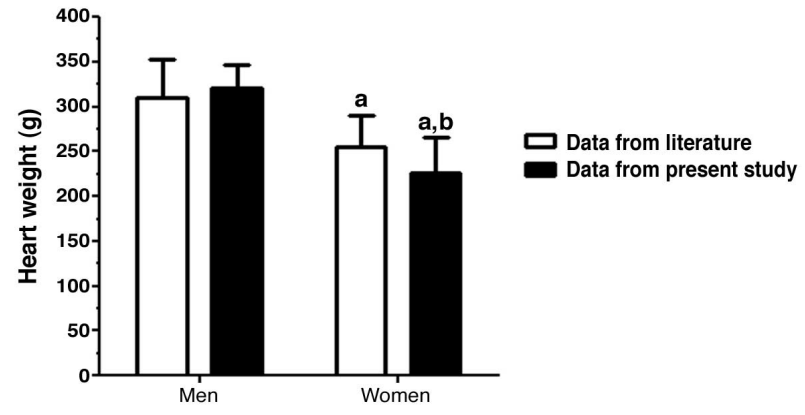

Fig. 1. Heart weights from groups. Data were tested using one way ANOVA followed Newmann-Keuls post-hoc test $(\mathrm{a}=$ different from respective male group; $b=$ different from data from literature).

Anatomy of coronary arteries. In all cases studied, both coronary arteries were present. Coronaries appeared in pairs as ascendant aorta initial segment branches rising from either left or right valves sinus.

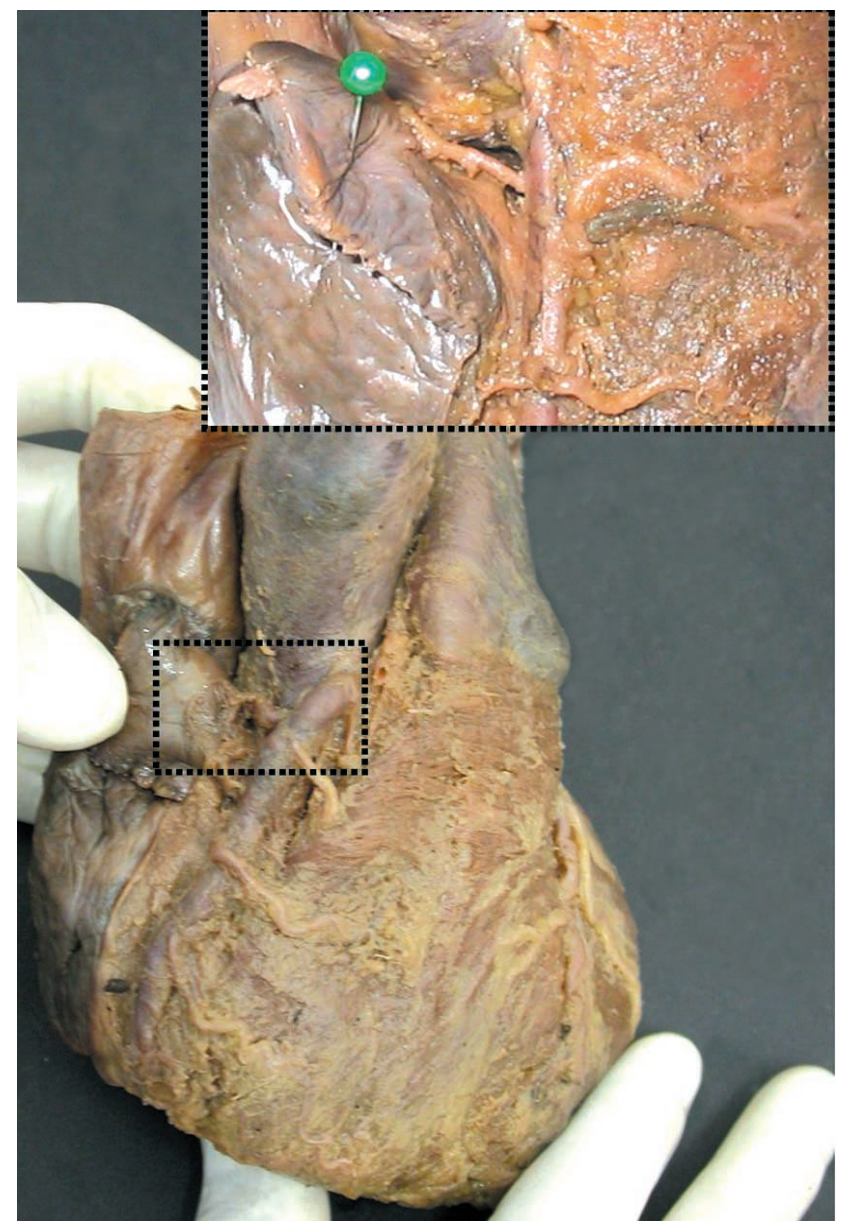

Fig. 2. Human heart from male with sinoatrial nodal artery dominance. Area marked in dashed line is showed right-upper through other figure with major magnification. It is possible to observe a prominence of sinoatrial nodal artery dominance (arrow).

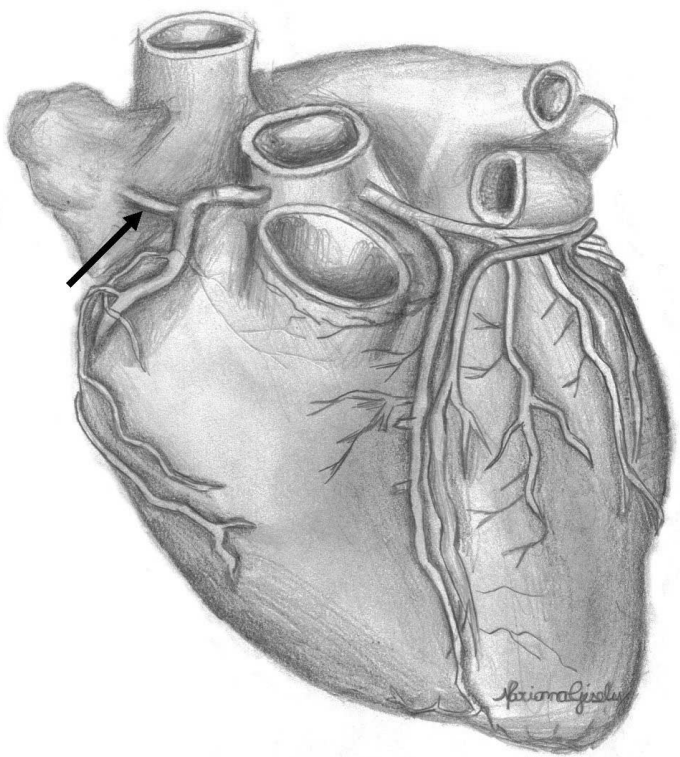

Fig. 3. Drawing of heart with localization from sinoatrial nodal artery dominance. 
Frequency of coronary arteries. None of the cases were characterized of arterial co-dominance. In one hand, the incidence of right coronary arterial dominance was $80 \%$ in men and $100 \%$ in women. On the other hand, the incidence of left coronary arterial dominance was $20 \%$ in men but it was not seen in women.

\section{DISCUSSION}

In the present study we analyzed heart weights and the incidence of coronary arterial dominance in thirty adult human hearts. We found that male hearts are heavier than female ones. Also, we noticed that right coronary branch irrigated SAN in most of the cases regardless gender. Heart weight is related to the weight of the individual. Generally, men are heavier than women and, therefore, their hearts are also heavier. This relationship in not true in pathological cases, where ventricle hypertrophy is present (Gray \& Mayo; Mandarim-de-Lacerda).

The coronary arteries supply blood to the myocardium and sinoatrial node is known as the natural mark pass of the heart. SAN was first described by Keith \& Flack in 1907 and it is located on the terminal sulk, and walks laterally with the superior vena cava and the right atrium (Truex et al., 1967).

Anatomical variation of coronary dominance is defined by the presence of a coronary branch irrigating SAN, which could be originated from either right or left coronary artery (Mandarim-de-Lacerda). In the present study, right coronary artery branch was found to be responsible for the irrigation of SAN in $80 \%$ of the cases in men and $100 \%$ in women. In 1961, James tightly described the anatomy of coronary arteries, and has illustrated the incidence of right dominance, more than $52 \%$, in adult individuals.

Many authors have also described similar findings in humans using distinct technical apparatus, such as angiography (Vieweg et al., 1975; Kyriakidis et al., 1983), observations made through surgery techniques (Busquet et al., 1984) and others (DiDio \& Wakefield, 1975; Von Lüdinghausen, 1987). However Doménech \& Orts-Llorca (1975) have observed that SAN irrigation may also occur from the circumflex artery, but such case is extremely rare. Mandarim-de-Lacerda et al. (1985) have described the morphology of such artery as spiralized at the SAN region. This characteristic, also seen in rats may improve nodal tissue irrigation without increasing artery caliber (Meloda-Silva \& Mandarim-de-Lacerda, 1990).

The present results describe a higher right coronary dominance in all cases studied regardless gender and differences on heart weight were similar to those found in literature descriptions.

\section{ACKNOWLEDGMENTS}

USS (Universidade Severino Sombra), FAPERJ (Fundação Carlos Chagas Filho de Amparo a Pesquisa do Estado do Rio de Janeiro) and UERJ (Universidade do Estado do Rio de Janeiro), Brasil.

BEZERRA, S. F.; NAGATO, C. A.; VIEIRA, J. C. L.; REIS, A. L. NOVAIS, L. \& VALENÇA, S. S. Estudio de dominancia de la arteria sinoatrial nodal en treinta corazones humanos de brasileños. Int. J. Morphol., 26(1):47-50, 2008.

RESUMEN: Fueron utilizados treinta corazones de individuos adultos, 15 de individuos de sexo masculino y 15 femeninos, del Instituto de Anatomía de la Universidade de Severino Sombra, Brasil. Después de una incisión paramediana esternal, fue realizada una disección para exponer e identificar la arteria del nodo sinoatrial (NSA), una rama derecha o izquierda de la arteria coronaria. Si el NSA está irrigado por la rama coronaria derecha, el dominio es derecho. Igual para la arteria coronaria izquierda. En los casos en que el NSA está irrigado por ambas arterias, se denomina codominancia. Los datos recogidos, masa de los corazones y género, fueron comparados con informes anteriores a través de la prueba de análisis de varianza (ANOVA unidireccional) y de la prueba post-hoc de Newman-Keuls con un nivel de significancia de $\mathrm{p}<0.05$. Los grupos fueron definidos como: MHL - corazones de los individuos masculinos recogidos de la literatura; FHL - corazones de individuos femeninos recogidos de la literatura; MHS - corazones de los individuos masculinos, del actual estudio; FHS - corazones de individuos femeninos, del actual estudio. Al comparar el peso de los corazones entre los grupos, MHL pesó $22 \%$ más que el grupo de FHL ( $<<0.05$ ); el grupo MHS pesó $41 \%$ más que grupo de FHS ( $<<0.05$ ). Solamente en FHS eran $11 \%$ más livianos que en FHL ( $\mathrm{p}<0.05$ ). De los corazones estudiados, presentaron dominancia coronaria derecha, $80 \%$ en los hombres y $100 \%$ en las mujeres. Sólo el $20 \%$ presentó dominancia coronaria derecha en los hombres. No hubo casos de codominancia en los corazones estudiados. Los actuales resultados indican que la dominancia coronaria derecha era más alta en todos los casos estudiados independiente del género y las diferencias en peso del corazón eran similares a las encontradas en la literatura.

PALABRAS CLAVE: Corazón; Arterias coronarias; Dominancia arterial. 


\section{REFERENCES}

Busquet, J.; Fontan, F.; Anderson, R. H.; Ho, S. Y. \& Davies, M. J. The surgical significance of the atrial branches of the coronary arteries. Int. J. Cardiol., 6(2):223-36, 1984.

DiDio, L. J. \& Wakefield, T. W. Coronary arterial predominance or balance on the surface of the human cardiac ventricles. Anat. Anz., 137(1-2):147-58, 1975.

Doménech, M. D. \& Orts-Llorca, F. Origen insólito de la arteria del nodo sino-atrial a partir de la arteria cincunfleja auricular izquierda. Rev. Españ. Cardiol., 28(4):357-60, 1975.

Flaci Jr, R. Anatomia das coronárias. Rev. Med., 72(1/4):214, 1994.

Fox, C.; Davies, M. J. \& Webb-Peploe, M. M. Length of left main coronary artery. Heart, 35:796-8, 1973.

Gray, H. \& Mayo, C. Gray: Anatomia. São Paulo, Guanabara Koogan, 1988.

James, T. N. The sinus node artery. The anatomy of the coronary arteries. New York, Paul B. Horber INC, 1961.

Keith, A. \& Flack, M. The form and nature of the muscular connections between the primary divisions of the vertebrate heart. J. Anat. Physiol., 41(3):172-89, 1907.

Kyriakidis, M. K.; Kourouklis, C. B.; Papaioannou, J. T.; Christakos, S. G.; Spanos, G. P. \& Avgoustakis, D. G. Sinus node coronary arteries studied with angiography. Am. J. Cardiol., 51(5):749-50, 1983.

Mandarim-de-Lacerda, C. A.; Hidden, G. \& Hureau, J. Morfologia do nó sino-atrial e sua vascularização no coração de natimorto termo. Arq. Bras. Cardiol., 44(2):107-9, 1985.

Mandarim-de-Lacerda, C. Anatomia do coração clinica e cirúrgica. Rio Janeiro, Revinter, 1990.

Melo-da-Silva, A. \& Mandarim-de-Lacerda, C. A. Morfologia e reconstrução anatômica do nó sino-atrial e da artéria do nó sino-atrial no coração de Rattus novergicus. Rev. Brasil. Ciências Morfol., 11(1): 82-8, 1994.

Sañudo, J. R.; Mirapeix, R. M.; Da Silva, N. \& Reig, J. Right coronary artery arising from the left aortic sinus in a heart with left coronary dominance: a post-mortem description-a case report. Angiology, 49(3):239-42, 1998.

Truex, R. C.; Smythe, M. Q. \& Taylor, M. J. Reconstruction of the human sinoatrial node. Anat. Rec., 159(4):371-8, 1967.

Vieweg, W. V.; Alpert, J. S. \& Hagan, A. D. Origin of the sinoatrial node and atrioventricular node arteries in right, mixed, and left inferior emphasis systems. Cathet. Cardiovasc. Diagn.,1(4):361-73, 1975.

Von Lüdinghausen, M. Clinical anatomy of cardiac veins, Vv. cardiacae. Surg. Radiol. Anat., 9(2):159-68, 1987.

\section{Correspondence to:}

Prof. Dr. Samuel Santos Valença

Laboratório de Reparo Tecidual

Departamento de Histologia e Embriologia

Universidade do Estado do Rio de Janeiro.

Av. Professor Manoel de Abreu, 444 - 3 andar - Maracanã, Rio de Janeiro

BRASIL

Tel : 552125876509

Fax: 552125876511

Received: 19-08-2007

Accepted: 17-11-2007 